J. Perinat. Med. 14 (1986) 189

\title{
External cephalic version: a clinical experience
}

John P. O'Grady, Jean-Claude Veille, Robert L. Holland, and Katherine A.
Burry

Department of Obstetrics and Gynecology, Oregon Health Sciences University, Portland, Oregon, U.S.A.

\section{Introduction}

The elective vaginal delivery of breech presentation infants has become less frequent due to the concern of clinicians about perinatal morbidity and mortality. Thus, cesarean delivery for breech presentation has increased to reduce or avoid fetal trauma and/or asphyxia [5]. However, the risks of vaginal breech delivery can be avoided if the fetus is manipulated from breech to cephalic presentation by external cephalic version (ECV) $[6,9,13,14,16,17,18,20,21]$. Randomized prospective studies have indicated that 3rd trimester ECV performed with tocolysis following real time ultrasound and cardiotocography screening, involves minimal fetal risk and is $60-90 \%$ successful $[9,18]$. As the role for late third trimester ECV is not established in pregnancies with breech presentation, we initiated a prospective clinical trial of ECV to evaluate the safety and utility of the procedure. Our experience constitutes the basis for this report.

\section{Materials and methods}

101 patients with normal pregnancy, from private and university services were referred for ECV (figure 1) and prospectively managed by protocol. Entry requirements were breech presentation at $\geq 35$ weeks from the last menstrual period and normal gestation.

\section{Curriculum vitae}

John Patrick O'Grady, M.D., was born in Dallas, Texas in 1945. He graduated from Stanford University with a Bachelor's and Master's Degree in Anthropology in 1969 and received his Medical Degree from Yale University in 1972. Following Residency Training at Yale New-Haven Hospital and a

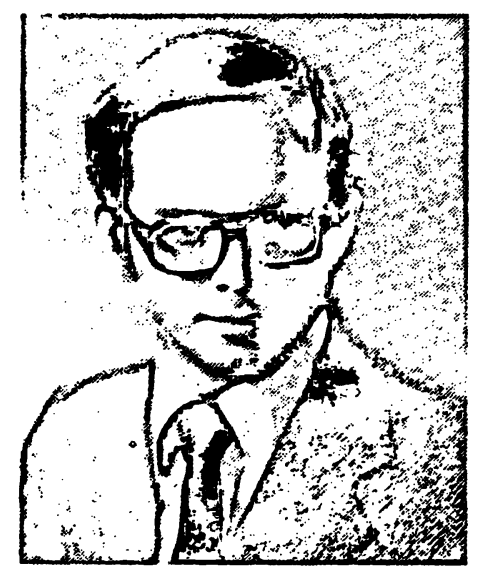
Fellowship at The King-Drew Medical Center, he joined the Faculty at Oregon Health Sciences University. Currently, he is Associate Professor of Obstetrics and Gynecology and Chief: Maternal Fetal Medicine at the MacDonald Hospital for Women, Case Western Reserve University, Cleveland, Ohio.

Patients excluded from consideration for trial included those with: 1) a fixed, engaged presenting part; 2) multiple gestation; 3) serious medical disorders of pregnancy (e. g. insulin-requiring diabetes, hypertension, etc.); 4) known or suspected fetal anomaly; and 5) known or suspected serious pregnancy complications (e. g., premature membrane rupture, abruptio placentae etc.). Initial screening was performed by clinicians who then referred selected patients to our research unit for the ECV protocol.

A screening real time ultrasound examination and an unstressed cardiotocogram (NST) was 


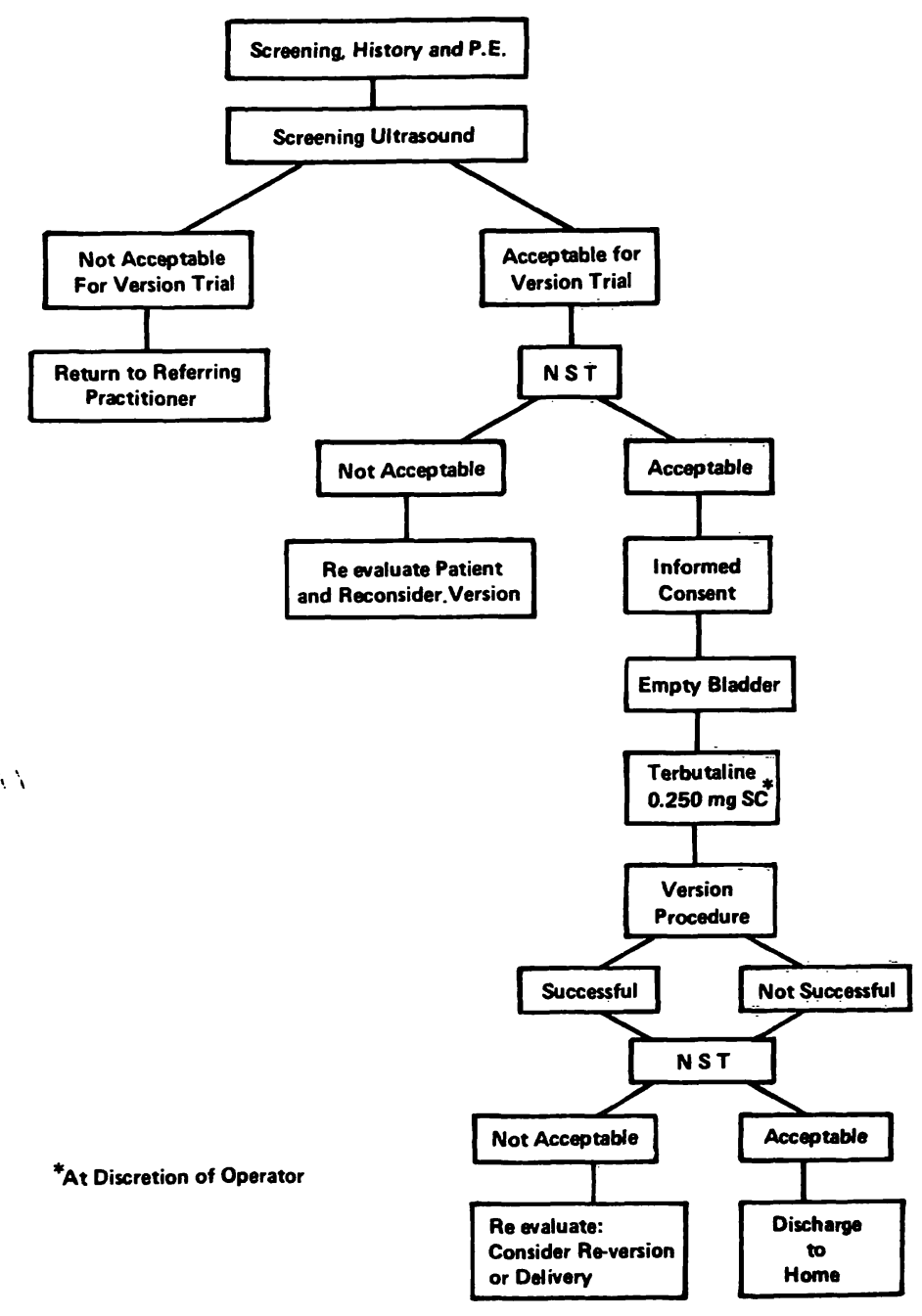

Figure 1. Version protocol.

performed. The NST was classified as reactive and acceptable if two or more fetal heart rate accelerations of $\geq 15$ bps for $\geq 15$ seconds was observed over 20 minutes. Gestational age was established by menstrual dating and ultrasonic examination based on biparietal diameter, head/body ratio and long bone length. Discrepancies exceeding \pm 2 weeks were reconciled by pediatric examination of the neonate utilizing DuBOwITZ criterion with reassignment of dating if appropriate.

Following informed consent, $0.25 \mathrm{mg}$. of terbutaline sulfate was administered subcutaneously. Only a single injection was given. Manipulations were performed 30 minutes later. Mineral oil was applied as a maternal abdominal lubricant. Versions were performed with the patient supine in Trendelenberg's position. A head- over-heels technique with the operation at the patient's right side was preferred. Back-flips as described by SALING and MülLER-Holve [14] were performed if the initial procedure failed. Firm, but slow movements proved most successful. Following manipulations, the fetal heart was ultrasonically visualized, the rate observed, and fetal position confirmed. Finally, an additional electronic fetal heart rate monitoring was performed to assure fetal well being.

If two attempts in each direction failed to achieve version or the patient proved intolerant to manipulation, the procedure was terminated. $\mathrm{Rh}$ negative women were administered immunoglobulin if any manipulations, either successful or unsuccessful had been performed. KLEINHAUER-BETKE examinations were not performed. Following the procedure the patients were rested in left lateral recumbency until the cardiotocography was judged normal, thereafter they were discharged to home. Subsequent management was by standard clinical procedures of the responsible clinician.

Date was analyzed by Chi square or t-test analysis with $\mathrm{p} \leq 0.05$ accepted as the level indicating significance.

\section{Results}

We attempted version on 85 of 101 patients. Initial cephalic presentation [11], marked oligohydramnios [3], encephalocele [1], and a nonreactive, suspicious initial electronic monitoring tracing [1] led to candidate rejection (figure 2). In $53 / 85$ cases $(62.5 \%)$ ECV was successful.

Our requirements for gestational age for trial of ECV were based on clinical criteria, i. e., menstrual dating. We subsequently discovered that using 35 weeks as a minimum gestational age for referral resulted in a patient group with the eventual assignment of gestational ages ranging from 33 to 41 weeks (figure 3 ). When the date was evaluated for mean maternal age, gestational age and eventual delivery weight all were found to be unrelated to ECV success. However, parity was observed to be a significant factor (tables I, II). 


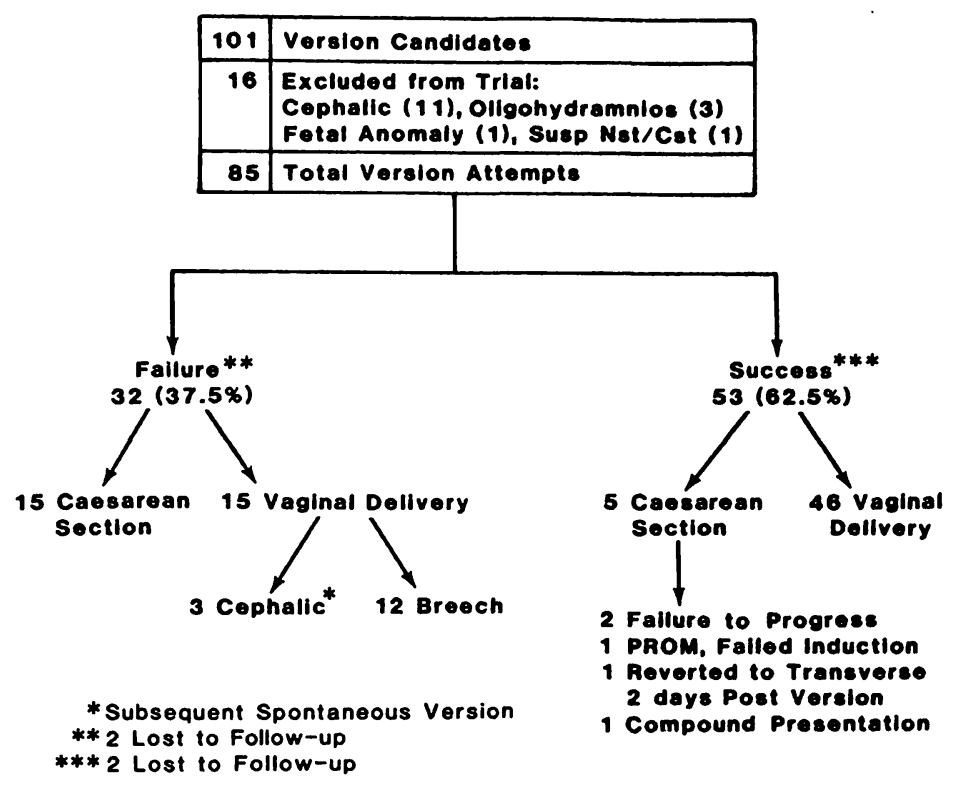

Figure 2. Results of version trials (see text for details).

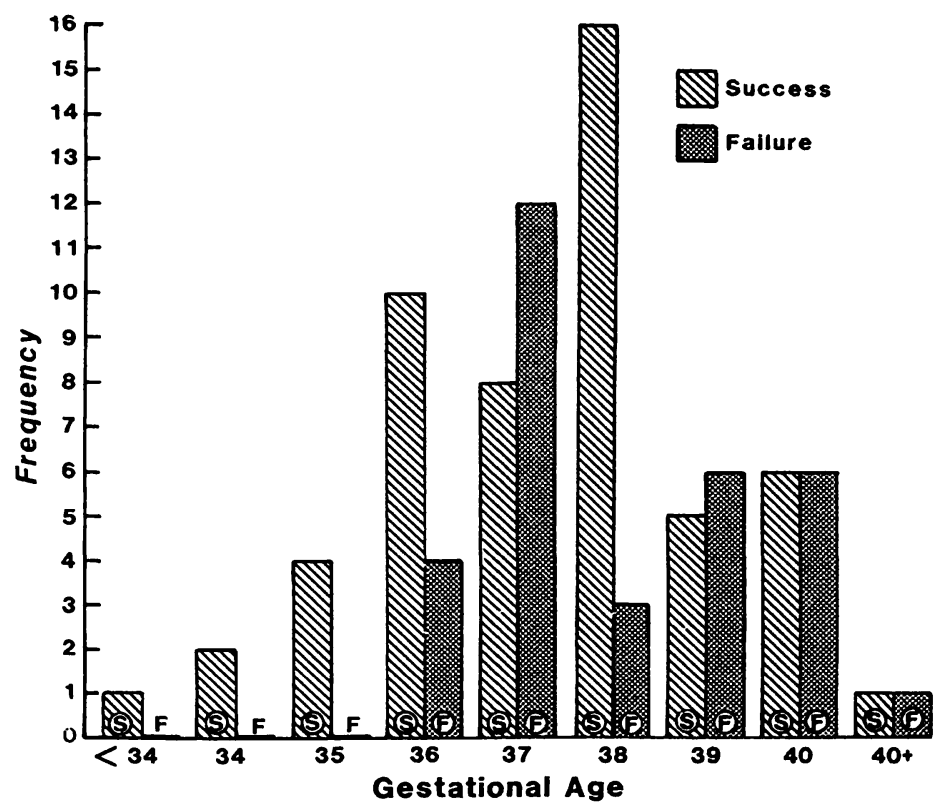

Figure 3. Success or failure of version attempts by gestational age (see text for details).

Table I. Version success and maternal age, gestational age, and delivery weight.

\begin{tabular}{lll}
\hline & $\begin{array}{l}\mathrm{N}=53 \\
\text { ECV success }\end{array}$ & $\begin{array}{l}\mathrm{N}=32 \\
\text { ECV failure }\end{array}$ \\
\hline Maternal age & $25.7 \pm 5.4$ yrs.** $^{* *}$ & $25.5 \pm 5.4$ yrs. \\
Gestational age & $38.0 \pm 1.5$ wkas. $^{* *}$ & $37.4 \pm 1.7$ wks. \\
Delivery weight & $3481 \pm 485$ gms.** $^{* *}$ & $3324 \pm 400$ gms
\end{tabular}

* Based on $\mathrm{N}=81,4$ patients lost to follow-up. See text for details.

** $\mathrm{p}=\mathrm{ns}$.
Table II. Version success and maternal parity.

\begin{tabular}{llll}
\hline Parity & $\begin{array}{l}\mathrm{N}=53 \\
\text { ECV sucess }\end{array}$ & $\begin{array}{l}\mathrm{N}=32 \\
\text { ECV failure }\end{array}$ \\
\hline 0 & $15(28.3 \%)$ & $\mathrm{p}<.005$ & $20(62.5 \%)$ \\
$\geq 1$ & $38(71.6 \%)$ & $12(37.5 \%)$ \\
\hline
\end{tabular}

Four patients $(4 / 85=4.7 \%), 2$ from each group, were lost to follow-up (figure 2). One gravida could not be contacted, two women had left the state, and one the country prior to delivery.

Fifty percent of the ECV failure patients subsequently delivered by cesarean section. However, abdominal delivery was required in only $9.8 \%$ $(5 / 51)$ of those cases in which version had been successful. Of interest, in three cases spontaneous version to cephalic presentation occurred after failed $\operatorname{ECV}(3 / 30=10.0 \%)$ (table III).

Table III. Cephalic presentation and cesarean section at delivery.

$\begin{array}{ll}\mathrm{N}=51^{*} & \mathrm{~N}=30^{*} \\ \mathrm{ECV} \text { success } & \mathrm{ECV} \text { failure }\end{array}$

Cephalic presen-

tation at delivery $50(98.1 \%) \quad p<.005 \quad 3(10.0 \%)$

Cesarean section $5(9.8 \%) \quad p<.00515(50.0 \%)$

* 4 patients lost to follow-up.

Table IV. Delivery complications.

\begin{tabular}{lll}
\hline & $\begin{array}{l}\mathrm{N}=51 \\
\text { success } \\
\text { group }\end{array}$ & $\begin{array}{l}\mathrm{N}=30 \\
\text { failure } \\
\text { group }\end{array}$ \\
\hline Cord around neck & 5 & 0 \\
Shoulder dystocia* & 1 & 1 \\
Marginal abruptio placentae & 1 & 0 \\
Cord prolapse & 1 & 0 \\
Meconium & 7 & 1 \\
5 Minute APGAR < 7 & $1^{* *}$ & $1^{* * *}$ \\
Compound presentation & 1 & 0 \\
\hline
\end{tabular}

* Both infants cephalic at delivery. Not fetal or maternal injury.

** Lethal congenital cardiac defect.

*** Meconium aspiration during vaginal breech delivery. 
Table IV outlines the complications observed in the 81 cases for which complete delivery data is available.

\section{Discussion}

External manipulation of the fetus can convert $60-90 \%$ of breech presentations to cephalic depending upon technique, the skill of the operator, use of tocolysis, and the population selected for trial $[6,7,9,13,14,16,18,20,21]$.

The relative influence of gravity, uterine shape, or placentation in eventual fetal polarity is not established $[15,19]$. At the beginning of the 3rd trimester, $20-30 \%$ of fetuses present by the breech. However, as gestation proceeds, enlargement of the fetus, diminution of amniotic fluid volume, and adjustment of the uterus predispose to cephalic presentation. Studies of fetal life note that the infant spontaneously assumes a cephalic presentation by the 34th week of gestation in all but $2-4 \%$ of normal pregnancies [19]. Thus, if version is attempted in the early 3rd trimester it is often easy, but frequently unnecessary, and re-version may occur. However, once a pregnancy passes into the late 3rd trimester, spontaneous version is uncommon $(\leq 15 \%)$, and the probability of the existing presentation persisting to term is high. These facts must be considered in the critical evaluation of the role of ECV in the obstetrical management of malpresentation.

In this study, 16 of 101 patients were excluded from trial of version by the combined results of real time ultrasonic scanning and EFM. In one case, with spontaneous contractions, suspicious decelerations occurred in a pregnancy in which the fetus was found to be growth retarded. In the other instance, a large fetal encephalocele was observed on the initial ultrasound scan. On initial scanning 11 fetuses were found to be in cephalic presentation and version was not attempted. Marked oligohydramnios led to the exclusion of 3 additional cases early in the course of the study. Yet, one serious fetal anomaly was missed. We evaluated and successfully verted a fetus that subsequently proved to have aortic atresia. This infant tolerated labor and was delivered vaginally, but succumbed on day four during attempted corrective surgèry.

Transient fetal heart decelerations frequently accompany version attempts and were observed in this series [16]. In some instances maternal symptoms implied a supine hypertensive syndrome likely exacerbated by the abdominal manipulations of version. In most circumstances, however, the changes were of unestablished cause but were likely due to transient cord compression. In our series, re-version for persisting fetal bradycardia was never necessary and in no instance was acute delivery required for conditions arising from the procedure. However, one compound (head/arm) presentation occurred following version. In this case, dystocia ensued during labor and operative delivery was necessary. Such complications, albeit uncommon, have been previously observed [1].

The single serious fetal complication in this series, meconium aspiration, occurred in a vaginally delivered breech infant. An unsuccessful version attempt had occurred 16 days previously. While meconium was present in 8 additional cases, in none was it associated with fetal distress. A larger series is needed to establish any association between the manipulations of version and meconium passage. The other complications observed, cord prolapse, and a marginal abruptio placentae occurred more than 10 days after ECV and are difficult to ascribe to the procedure.

Clinically, failure to elevate the presenting part was the most consistent cause of ECV failure. We could not discern specific ultrasonic findings that others have reported $[7,10,20]$ predicting success in version, except engagement of the breech. In our series attempted vaginal manipulations to dislodge an engaged breech were in all but one instance unsuccessful as well as uncomfortable for the patient. In addition, neither placental locale nor low amnionic fluid volume (unless marked oligohydramnios was present) modified our version protocol. None of the gravids examined in this series had clinical or ultrasonic evidence of placentation suffi- 
ciently low lying to permit the diagnosis of placenta previa. Further, we did not observe differences in success based on placental localization.

Initially, we utilized terbutaline tocolysis only in cases in which initial manipulation failed to achieve easy version. However, we soon discovered that betamimetic assisted version was easier for both patient and operator, and thereafter, we administered tocolytics routinely (overall in $43 / 85$ or $50.5 \%$ ). Betamimetics are not without serious complications, but neither we nor others have observed complications from acute administration for ECV $[6,14,18]$. Terbutaline was chosen because of our successful prior experience with this agent; the route of administration by convenience and economy.

Due to the fact that our patients frequently traveled long distances for the procedure and with uncertainties of patient follow-up, we routinely administered immune globulin to all $\mathrm{Rh}$ negative patients with an ECV attempt [9, $11,12]$. In series in which KLEINHAUER-BETKE studies have been performed, $4-28 \%$ of version patients have shown evidence of measurable fetomaternal bleeding $[8,16]$.

\section{Summary}

Eighty-five normal women underwent external cephalic version (ECV) for breech presentation in the late 3rd trimester (figures 1,2 ). The protocol included real time ultrasonic scanning and pre- and post-procedure electronic fetal monitoring. Subcutaneous terbutaline sulfate $(0,25 \mathrm{mg}$.) was administered to $(43 / 85$ or $50.5 \%)$ of $\mathrm{ECV}$ candidates and rendered the procedure easier for patient and operator. A single operator, head-over-heels technique assisted by supine TRENDELENBERG's position was used. $\mathrm{Rh}$ negative women were routinely administered $300 \mathrm{mcg}$ of immune globulin. Successful ECV (53/85, $62.5 \%$ ) was related to maternal parity, but not to gestational age nor eventual delivery weight (tables I, II). There were no acute maternal or fetal complications referrable to ECV. One neonatal loss occurred due to a lethal congenital cardiac anomaly (table IV). In this series only engagement of the breech was reliable in predicting ECV failure.

Fifty of $51(98.1 \%)$ successfully verted women delivered a cephalic presentation infant at term. Cesarean section was performed in $5 / 51$ of these patients $(9.8 \%)$ for
Based on our experience, factors important to the success and safety of late third trimester version include:

1) Operator experience and careful patient selection,

2) The use of firm but smooth movements during manipulation,

3) Screening by both real time ultrasound and electronic fetal heart rate monitoring,

4) The use of tocolysis,

5) A setting permitting prompt intervention if required.

In sum, while the numbers involved in this trial are limited, we conclude that major risks do not accompany late 3 rd trimester version if reasonable care is taken and careful pre-attempt fetal evaluation is performed. However, practitioners and patients need to remain aware that fetal manipulations cannot invariably be free from complications $[1,2,3,4,8,12]$. Thus, it seems prudent to carefully evaluate the fetus both anatomically as well as biophysically prior to an attempt at version in a setting where intervention, if indicated, is possible.

routine obstetrical indications. In one case, compound presentation at term resulting in dystocia and eventual cesarean section was believed related to prior successful version. In contrast, $15 / 30(50 \%)$ of the ECV failure patients went on to operative delivery despite a liberal institutional policy toward term vaginal breech trials. In addition, the only serious fetal complication in this series, meconium aspiration, occurred in a vaginally delivered breech infant (tables III, IV).

It is unlikely that late 3rd trimester ECV will impact on our overall rate of cesarean delivery. In North America prematurity is the greatest risk factor in malpresentation and our policy increasingly is to permit attempts at term breech vaginal delivery. Nonetheless, ECV deserves serious consideration. When successful, ECV avoids the costs and/or risks of either cesarean section or vaginal trial of breech. As opposed to version practiced earlier in gestation, the merit of late 3rd trimester ECV is that more than $80 \%$ of spontaneous versions will have occurred by the time the procedure is attempted. Thus, most successful late version procedures occur in cases 
where spontaneous conversion is unlikely. In addition, babies successfully verted late in gestation are unlikely to spontaneously revert to breech $(1 / 51$ or $2 \%$ in our series). if

Under the protocol described herein, and in a limited series of patients, we have found late 3rd trimester ECV $62.5 \%$ successful and clinically safe.

Keywords: Breech presentation, external cephalic version, late pregnancy tocolysis.

\section{Zusammenfassung}

Äußere Wendung - ein klinischer Erfahrungsbericht Wegen Beckenendlage (BEL) im fortgeschrittenen dritten Trimenon wurde bei 85 Frauen eine äußere Wendung vorgenommen (Abb. 1, 2). Zur Protokollierung gehörten eine Ultraschall-Untersuchung sowie ein elektronisches Monitoring des Feten vor und nach der Wendung. Durch subkutane Injektion von $0,25 \mathrm{mg}$ Terbutalinsulfat bei 43 von 85 Frauen $(50.5 \%)$ wurde der Vorgang für Patient und Operateur erleichtert. Die Wendung wurde im Sinne einer Rückwärtsrolle des Feten durch eine Person ausgeführt. Rh-negativen Frauen wurde routinemäßig $300 \mu \mathrm{g}$ Anti-D verabreicht. Die erfolgreichen Wendungen ( 53 von 85 , d. h. $62.5 \%$ ) wurden zur Parität, nicht aber zum Gestationsalter oder zum geschätzten Geburtsgewicht in Beziehung gesetzt (Tabellen I, II). Akute mütterliche oder fetale Komplikationen, die auf die Wendung zurückzuführen waren, traten nicht auf. Ein neonataler Todesfall war auf eine angeborene letale Herzmißbildung zurückzuführen. Über den Erfolg bzw. Mißerfolg einer Wendung entschied in der Untersuchungsreihe allein die Lage des Steißes.

50 von 51 Frauen mit erfolgreicher Wendung $(98,1 \%)$ wurden am Termin von einem Kind aus Schädellage entbunden. Dabei war bei 5 der 51 Frauen $(9,8 \%)$ aus verschiedenen geburtshilflichen Gründen eine Sectio indiziert. In einem Fall kam es am Termin zu einer Dystokie und schließlich zu einer Sectio; hier glauben wir, einen Zusammenihang zu der vorher erfolgreich durchgeführten Wendung herstellen zu können. Auf der anderen
Seite wurden 15 von 30 Frauen (50\%) nach erfolgloser Wendung per Sectio entbunden, obwohl wir bezüglich vaginaler BEL-Geburten einen liberalen Standpunkt einnehmen. Die einzige ernsthafte Komplikation, eine Mekoniumaspiration, trat in unserer Untersuchungsreihe jedoch bei einem Kind nach vaginaler BEL-Geburt auf (Tabellen III, IV).

Es ist unwahrscheinlich, daß eine Wendung im fortgeschrittenen dritten Trimenon einen Einfluß auf die Gesamtsectiorate hat; in Nordamerika ist Frühgeburtlichkeit der größte Risikofaktor für BEL. Ein anderer Punkt ist die Haltung zu vaginalen BEL-Geburten am Termin. Trotzdem soll die äußere Wendung ernsthaft erwogen werden; ist sie erfolgreich, werden Kosten und Risiken einer Sectio bzw. einer vaginalen BEL-Geburt vermieden. Der Hauptvorteil gegenüber einem frühen Wendungsversuch liegt darin, daß bei der Wendung im fortgeschrittenen dritten Trimenon mehr als $80 \%$ der Wendungen bereits spontan erfolgt sind. Die späten Wendungsversuche werden also dann durchgeführt, wenn eine spontane Drehung unwahrscheinlich ist. Hinzu kommt, daß nach einer erfolgreichen späten Wendung das Zurückdrehen in die BEL unwahrscheinlich ist (1 von 51 bzw. $2 \%$ in unserer Untersuchungsreihe).

Bei der beschriebenen Vorgehensweise und dem begrenzten Kollektiv können wir sagen, daß die äußere Wendung im fortgeschrittenen dritten Trimenon in $62,5 \%$ der Fälle erfolgreich und klinisch sicher war.

Schlüsselwörter: Äußere Wendung, Beckenendlage, Tokolyse in der Spätschwangerschaft.

\section{Résumé}

Version par manoeuvres externes - expérience clinique Quatre-vingt cinq femmes normales ont subi une version par manœuvres externes (VME) à la fin du troisième trimestre pour une présentation du siège (figures 1,2 ). Le protocole comprenait une échographie en temps réel et un enregistrement du rythme cardiaque fotal avant et après les manœuvres. On a administré en sous-cutané du sulfate de terbutaline $(0.250 \mathrm{mg}) \cdot \mathrm{à} 43$ canditates à la VME sur $85(50,5 \%)$ ce qui facilitait les manœuvres pour les patientes et pour l'opérateur.

Un seul opérateur utilisait la technique de la tête sur les talons aidé d'une position de trendelenbourg. Les fem- mes rhesus négatif ont reçu systématiquement $300 \mathrm{mcg}$ de gammaglobuline. Les succès de la VME (53/85; $62,5 \%)$ sont corrélés à la parité maternelle, mais ni à l'âge gestationel, ni au poids de naissance (tableaux I, II). Il n'y a pas eu de complication aigüe maternelle ou foetale implicable à la VME. Un décès néonatal est survenu, secondaire à une anomalie cardiaque congénitale léthale (tableau IV). Dans cette série, seul l'engagement du siège était corrélé à la prévision d'un echec de la VME.

Cinquante des $51(98,1 \%)$ ayant eu une version efficace ont donné naissance, à terme, à un enfant en présenta- 
tion céphalique. Chez ces patientes, une césarienne a été pratiquée 5 fois/51 $(9,8 \%)$ pour des indications obstétricales de routine. Dans un cas, un procubitus d'un membre à terme a entrainé une dystocie et on a considéré la césarienne comme secondaire à la version efficace antérieure. A l'inverse 15/30 (50\%) des patientes ayant eu un échec de la VME ont subi une césarienne malgré une attitude institutionelle libérale face aux sièges à terme. En outre, la seule complication fœtale sévère dans cette série, à savoir une inhalation méconiale, est survenue chez un enfant en présentation du siège né par voie vaginale (tableau III, IV).

Il est peu probable que la VME à la fin du troisième trimestre influencera le taux global de césarienne en Amerique du Nord et ceci pour deux raisons: la première est que la prématurité est encore le facteur de risque le plus important pour la présentation défavorables, et la deuxième est du à une politique plus libérale de l'accou- chement du siège par voie basse à terme. Néanmoins, la VME mérite une considération importante. Lorsqu'elle réussit la VME évite le coût et/ou les risques de la césarienne et de l'accouchement du siège par voie basse. A l'opposé de la version pratiquée plus tôt au cours de la grossesse, le mérite de la VME à la fin du troisième trimestre est que plus de $80 \%$ des versions spontanées auront déjà eu lieu au moment de la tentative. Ainsi, beaucoup de versions efficaces par monœuvres externes tardives surviennent dans des cas où la version spontanée est peu probable. En outre, les fotus versés en présentation céphalique tardivement au cours de la grossesse ont peu de risque de se retourner spontanément en siège (1/ 51 ou $2 \%$ dans notre série).

Selon le protocole décrit ci-dessus et dans une série limitée de patientes, nous avons trouvé que la VME à la fin du troisième trimestre à $62,5 \%$ de succès et qu'elle est cliniquement sans danger.

Mots-clés: Présentation du siège, tocolyse de fin de grossesse, version par manœuvre externe.

Acknowledgements: The paper was presented in part at the Society of Perinatal Obstetricians Annual Meeting February 2-4, 1984, San Antonio, Texas.

\section{References}

[1] ANG LT: Compound presentation following external version. Aust NZ Obstet Gynaecol 18 (1978) 213

[2] Berg D, U Kunze: Critical remarks on external cephalic version under tocolysis. Report on a case of antepartum fetal death. J Perinat Med 5 (1977) 32

[3] BRADLEY-WATSON PJ: The decreasing value of external cephalic version in modern obstetric practice. Am J Obstet Gynecol 123 (1975) 237

[4] BRosset A: The value of prophylactic external version on cases of breech presentation. Acta Obstet Gynecol Scand 35 (1956) 555

[5] Collea JV: The intrapartum management of breech presentation. Clin Perinatol 8 (1981) 173

[6] FALL O, BA NiLsSON: External cephalic version in breech presentation under tocolysis. Obstet Gynecol 53 (1979) 712

[7] Fianu S, V Vaclavinkova: External cephalic version in the management of breech presentation with special reference to the placental location. Acta Obstet Gynecol Scand 58 (1979) 209

[8] GJode P, TB Rasmussen, J Jorgensen: Feto-maternal bleeding during attempts at external version. Br J Obstet Gynaecol 87 (1980) 571

[9] HOFMEYR GJ: Effect of external cephalic version in late pregnancy on breech presentation and cesarean section rate: A controlled trial. Br J Obstet Gynaecol 90 (1983) 392
[10] KIRKINEN P, P Ylostalo: Ultrasonic examination before external version of breech presentation. Gynecol Invest 13 (1982) 90

[11] Marcus RG, H Crewe-Brown, S Krawitz, J KATZ: Fetomaternal haemorrhage following successful and unsuccessful attempts at external cephalic version. Br J Obstet Gynaecol 82 (1975) 578

[12] PollaCK A: Transplacental hemorrhage after external cephalic version. Lancet 1 (1968) 612

[13] RANNEY B: The gentle art of external cephalic version. Am J Obstet Gynecol 116 (1973) 239

[14] Saling E, W Muller-Holve: External cephalic version under tocolysis. J Perinat Med 3 (1975) 115

[15] Stevenson CS: Certain concepts in the handling of breech transverse presentations in late pregnancy. Am J Obstet Gynec 62 (1951) 488

[16] Stine LE, JP Phelan, R Wallace, GS Eglinton, JP VAN DORSTEN, BS SCHIFRIN: Update on external cephalic version performed at term. Obstet Gynecol 65 (1985) 642

[17] VAN DORSTEN JP: Safe and effective external cephalic version with tocolysis. Contemp Obstet Gynecol 19 (1982) 44

[18] VAN Dorsten JP, BS ShIfrin, RL Wallace: Randomized control trial of external cephalic version with tocolysis in late pregnancy. Am J Obstet Gynecol 141 (1981) 417 
[19] VARTON CK: The behavior of the foetus in utero with special reference to the incidence of breech presentation at term. J Obstet Gynaecol Br Cwlth 52 (1945) 417

[20] YeAST JD, TJ GaRITE: External version for breech fetuses - a neglected alternative? Contemp Obstet Gynecol 25 (1985) 45

[21] Ylikorkala O, AL HaRTKaINEN-SoRRI: Value of external version in fetal malpresentation in combination with use of ultrasound. Acta Obstet Gynecol Scand 56 (1977) 63

\section{if}

Received September 10, 1984. Revised June 28, 1985. Accepted July 29, 1985.

John Patrick O'Grady, M.D. Chief, Maternal Fetal Medicine Associate Professor Department of Obstetrics and Gynecology University Hospitals of Cleveland MacDonald Hospital for Women 2065 Adelbert Road Cleveland, Ohio 44106, U.S. A. 